\title{
Density-dependent changes in the distribution of southern right whales (Eubalaena australis) in the breeding ground Peninsula Valdés
}

\author{
Nicolas Sueyro ${ }^{\text {Corresp., }}{ }^{1,2}$, Enrique Alberto Crespo ${ }^{1,2}$, Magdalena Arias ${ }^{3}$, Mariano Alberto Coscarella ${ }^{1,2}$ \\ ${ }^{1}$ Laboratorio de Mamíferos Marinos (LAMAMA), Centro para el Estudio de Sistemas Marinos (CESIMAR- CCT CENPAT-CONICET), Puerto Madryn, Chubut, \\ Argentina \\ 2 Facultad de Ciencias Naturales y Ciencias de la Salud, Universidad Nacional de la Patagonia San Juan Bosco, Puerto Madryn, Chubut, Argentina \\ Corresponding Author: Nicolas Sueyro \\ Email address: nicosueyro@cenpat-conicet.gob.ar
}

Background. Southern Right Whales (Eubalaena australis) population of the South-western Atlantic Ocean is recovering. In the breeding ground of Peninsula Valdés, as a consequence of the population growth, expansion to new areas by some types of groups and a change in the habitat use patterns at the coastal area were recorded.

Methods. We analyzed information gathered from aerial surveys conducted along the coast of Peninsula Valdés in 15 years of effective sampling in a 19-year span. These surveys were divided into 4 periods (1999-2000; 2004-2007; 2008-2012 and 2013-2016) and estimated the density of whales in a $620 \mathrm{~km}$ of coast divided into segments of $5 \mathrm{~km}$.

Results. The density of the whales increased to near 3 whales per km2 (averaged over each period) in the high-density areas. When this mean number was reached, the significant changes in density in the adjacent areas were detected in the following period. These changes were a decrease in density in the high-density areas and an increase of density in the low-density areas.

Discussion. We propose that a threshold in density elicits a response in habitat use, with the Mother-calf pairs remaining in the area, while the other groups are displaced to new areas. 
1 Density-dependent changes in the distribution of southern

2 right whales (Eubalaena australis) in the breeding ground

3 Peninsula Valdés

4

5 Nicolás Sueyro 1,2; Enrique A. Crespo 1,2; Magdalena Arias ${ }^{3}$; Mariano A. Coscarella ${ }^{1,2}$

6

$7{ }^{1}$ Laboratorio de Mamíferos Marinos (LAMAMA), Centro Para de Estudios de Sistemas Marinos

8 (CESIMAR-CCT CENPAT-CONICET). Puerto Madryn/Chubut, Argentina.

${ }^{2}$ Facultad Cs. Naturales y de la Salud - Universidad Nacional de la Patagonia San Juan Bosco (UNPSJB).

Puerto Madryn/Chubut, Argentina.

${ }^{3}$ Centro de Investigación Aplicada y Transferencia Tecnológica en Recursos Marinos Almirante Storni

12 (CIMAS). San Antonio Oeste/Río Negro, Argentina.

Corresponding Author:

Nicolás Sueyro ${ }^{1,2}$

Email address: nicosueyro@cenpat-conicet.gob.ar 


\section{Abstract}

Background. Southern Right Whales (Eubalaena australis) population of the South-western Atlantic Ocean is recovering. In the breeding ground of Peninsula Valdés, as a consequence of the population growth, expansion to new areas by some types of groups and a change in the habitat use patterns at the coastal area were recorded.

Methods. We analyzed information gathered from aerial surveys conducted along the coast of Peninsula Valdés in 15 years of effective sampling in a 19-year span. These surveys were divided into 4 periods (1999-2000; 2004-2007; 2008-2012 and 2013-2016) and estimated the density of whales in a $620 \mathrm{~km}$ of coast divided into segments of $5 \mathrm{~km}$.

Results. The density of the whales increased to near 3 whales per km2 (averaged over each period) in the high-density areas. When this mean number was reached, the significant changes in density in the adjacent areas were detected in the following period. These changes were a decrease in density in the high-density areas and an increase of density in the low-density areas. Discussion. We propose that a threshold in density elicits a response in habitat use, with the Mother-calf pairs remaining in the area, while the other groups are displaced to new areas.

\section{Introduction}

The Southern Right Whale (Eubalaena australis) has a circumpolar distribution in the southern hemisphere. This species was subjected to a commercial exploitation between the 19th and 20th centuries that put the species on the brink of extinction (Richards 2009). The species was protected for the first time in 1936 and additionally, in 1986, the moratorium on commercial catch established by the International Whaling Commission (IWC) came into force. By the mid1970's several populations have shown evidence of recovery, with a doubling time of 10 to 12 years (Bannister 2001; Best et al. 2001; Cooke et al. 2001). However, there are other populations that are still very small and there is uncertainty about their recovery (Galletti Vernazzani et al. 2014). Even today, the geographical distribution of all breeding and feeding areas of the species prior to its exploitation are unknown (IWC 2001).

The estimated population size for the species in 1997 was 7,500 animals (including 547 mature females, from Argentina and 659 from South Africa), with an estimated average growth rate for all populations in the Southern Hemisphere of 7.5\% (IWC 2012). The breeding population of Peninsula Valdés is one of the best studied, with a long-term research program carried out in the Peninsula Valdés area since 1970 (Payne 1986). The population size and other parameters 
47 derived from capture-recapture models have been estimated, based on the individual recognition of the whales. The population growth rate was estimated to be around $8 \%$ by the early 80 's (Payne 1986; Payne et al. 1981; Payne et al. 1990; Whitehead et al. 1986), and recent studies estimate a 5.1\% for 2010 (Cooke 2012) and 6.5\% for 2012 (Cooke et al. 2015) using the same techniques.

The process of gathering the information from photo-identification is time-consuming, and there was a need for a quick assessment of the number of whales and population trend by the authorities. In 1999 a protocol involving coastal aerial survey with the direct counting of marine mammals in the Peninsula Valdés area was started (Crespo et al. 2018). Crespo and colleagues estimated for the year 2007 an increasing rate of $6.22 \%$. For the year 2014, the models indicated that the population grew at a rate of $3.23 \%$ per year (Crespo et al. 2018). However, the reduction in the rate of increase was not uniform across the different groups that comprise the population. The estimate of the growth rate for offspring born in the Peninsula Valdés was 5.54\% per year between 1999 and 2014 (Crespo et al. 2018), almost doubling the rate of increase for the whole population during the same period. The rate of increase of the other class groups (namely Solitary Individuals and Breeding groups) is now close to 0\% (Crespo et al. 2018). During the first sampling seasons, all the types of groups were close to the coast. As the population grew the Mother-calf pairs remained close to the shore, while the other types of groups were displaced farther off from it. This change in Peninsula Valdés distribution could mean that the coastal zone (within $2 \mathrm{~km}$ from shore) is close to it carrying capacity (Crespo et al. 2018). Therefore, in spite of the overall decrease in the population increasing rate observed in the sampling area, it is proposed that the southern right whale stock of the south-western Atlantic is still growing at a rate that would be the combination of its growth in the Peninsula Valdés area and the occupation rate of other zones (Crespo et al. 2018). If this scenario is correct, whales should begin to move to other less dense regions (ie:, sub-optimal habitats) where the growth rate should be higher (Hobbs \& Hanley 1990; Verner et al. 1986). There are different indicators supporting this hypothesis for Peninsula Valdés as evidenced by the number of whales occupying areas with deeper waters in Peninsula Valdés and the growing number of whales observed in Golfo San Matías, Buenos Aires, Uruguay and Santa Catarina in southern Brazil (Crespo et al. 2018; Groch et al. 2005; IWC 2011). 
The expansion of whales to other areas may be determined by the priority occupation of mothers with offspring in optimal habitat areas (Barendse \& Best 2014; Carroll et al. 2014; Danilewicz et al. 2016). If this is the case, there should be a threshold density in which the Other groups increase their density in adjacent areas (eg: nonpreferred by Mother-calf pairs). Similar trends have also been recorded in other southern right whale stocks from South Africa, New Zealand and southern Brazil, where Solitary Individuals and Breeding Groups move to new sites, outside the established breeding area (Barendse \& Best 2014; Carroll et al. 2014; Danilewicz et al. 2016).

\section{Methods}

The censuses were carried out from a single-engine high-wing CESSNA B-182 aircraft, flying at a constant height of 500 feet $(152 \mathrm{~m})$ and at 80/90 knots every 45 days from April to December each year (Crespo et al. 2018). In each survey a distance of $620 \mathrm{~km}$ was covered in 5 hours of flight, flying from south to north along the coast. The surveyed area (Figure 1) is located between the mouth of the Rio Chubut and Puerto Lobos on the border with the province of Rio Negro. The width of the strip is composed by 500 meters from the coast plus approximately 1000 meters from the plane to the open sea, composing a surveyed strip of 1500 meters (Crespo et al. 2018). This strip is set to cover the "whale-road" as described by Payne (1986), where more than $90 \%$ of the whales in the area concentrate near the coast in shallow waters.

The team comprised a pilot, a recorder sitting next to the pilot and two observers in the rear seats, one on the left and one on the right side of the aircraft (Crespo et al. 2018). The observations were made with the naked eye, and the information was recorded in spreadsheets or tablet applications developed $a d-h o c$ with Cyber Tracker TM. Information on the group composition was recorded, including Mother-calf pairs, Solitary Individuals or Breeding groups comprising a female and several males (Crespo et al. 2018). For the analysis in this work Solitary Individuals and Breeding groups were pooled in Other groups, as a group category opposite to the Mother-calf pairs. Along with the type of group we recorded the position registered with a handheld GPS, the number of individuals and the sea state on the Beaufort scale. Flights were suspended when the visibility conditions were not optimal, either because of fog or the sea state exceeded the level 3 on the Beaufort scale. Data were entered into a database developed in Access-Microsoft ${ }^{\circledR}$ specifically for this purpose. Fields in the database included time and position, number of animals, side of the sighting, type of group, and other ancillary information. 
108 The information was grouped into four periods, making each period as similar as possible considering the number of flights. A total of 58 aerial surveys were clumped in four periods: period 1 from 1999 and 2000 (8 flights) and the other 3 periods comprised from 2004 to 2007 for period 2 (18 flights), period 3 from 2008 to 2012 (17 flights) and period 4 from 2013 to 2016 (15 flights). No flights were performed during the period 2001-2003.

The surveyed coast was divided into segments of $5 \mathrm{~km}$ in length, totalling 124 segments for the $620 \mathrm{~km}$ sampled in each flight, where the $0 \mathrm{~km}$ is the mouth of the Chubut River (Figure 2). The densities were calculated by dividing the number of whales counted in each segment, weighted by the number of flights performed per period and the area of each segment, calculated as the 5 $\mathrm{km}$ segment by $1.5 \mathrm{~km}$ (bandwidth), and thus each segment accounted for a $7.5 \mathrm{~km}^{2}$. The length of the segment was chosen following Rowntree et al. (2001), who divided the coast into $5 \mathrm{~km}$ segments to evaluate the distribution of the Southern Right Whales. Preliminary examination of data led us to define two high densities zones, one inside Golfo Nuevo from Puerto Madryn to Punta Cormoranes and other inside Golfo San José, from Punta Conos to Punta Tehuelche (Figure 3). These areas coincide with the ones defined previously by Rowntree et al. (2001) for the areas selected by whales in the early 90 's. We also defined the low-density zones as those outside the high-density zones (ie: Chubut River mouth-Puerto Madryn; Punta Cormoranes-Punta Conos; Punta Tehuelche-Puerto Lobos). Differences in densities among the periods in these zones were assessed by Mann-Whitney $U$ tests (Zar 2010). The permit was granted by the Secretaría de Turismo y Áreas Protegidas of the Province of Chubut, (issued for the last time under permit number 93-SsCyAP / 15).

\section{Results}

The overall density of both group categories for the whole surveyed area shows for the first period a similar density for Mother-calf pairs and Other groups. For the second period, the observed increase of density is similar for both categories (Figure 2). During the third and the fourth period, the density of Mother-calf pairs slightly increases, while the Other group's density decreases (Figure 2).

The coastal area defined as high densities zones are located between the segments 24 (Puerto Madryn) and 49 (Punta Cormoranes) (high-density l) within the Golfo Nuevo and between the segments 90 (Punta Conos) and 101 (Punta Tehuelche) (high-density 2) within the Golfo San José (Figure 3). The highest densities in any of the four periods were observed at the Doradillo 
139 (segment 28 and 29) and Playa Fracaso (segment 97 and 98), reaching a maximum estimated of 1403.15 whales per $\mathrm{km}^{2}$ during the first period for all type of groups.

141

142

143

144

145

146

147

148

149

150

151

152

153

154

155

156

157

158

159

160

161

162

163

164

165

166

167

168

169

Figure 4 shows the density changes in the two areas of high density of animals. In the high-

density 1, the Mother-calf pairs increased their density in the second and third period with respect to the first $\left(U_{1,2}: 181.5 / U_{1,3}: 157.5 ; \mathrm{p}<0.05\right)$ but a great variation was observed in the fourth period. The density of the Other groups category increases, but with a subsequent decrease $\left(U_{1,2}: 179 / U_{2,4}: 426 ; \mathrm{p}<0.05\right)$.

In the high-density 2, a similar pattern is observed, an increase in the density of Mother-calf pairs $\left(U_{1,3}: 41.5 ; \mathrm{p}<0.05\right)$ that is sustained in time. For the groups without calves or the Other groups, the initial increase is followed by a marked decrease in the last period $\left(U_{2,4}: 143 / U_{3,4}: 147.5 ; \mathrm{p}<\right.$ $0.05)$.

Figure 5 shows the changes in the low-density zones. Mother-calf pairs in the low-density 1 increased their density during the third period $\left(U_{2,3}: 215 ; \mathrm{p}<0.05\right)$. Also, an increase in the density of the Other groups from the first to the second period can be observed $\left(U_{1,2}: 205\right.$; $\mathrm{p}<0.05)$. Afterwards a decrease in the density from the second to the third $\left(U_{2,3}: 540 ; \mathrm{p}<0.05\right)$ was recorded to the groups without calves. In the low-density 2 the Mother-calf pairs increased their density only during the third period $\left(U_{1,3}: 489 / U_{2,3}: 437 / U_{3,4}: 1054 / \mathrm{p}<0.05\right)$ decreasing afterwards. For the Other groups there was an increase in the second period and it remained higher than the first period later $\left(U_{1,2}: 372 / U_{1,3}: 519.5 / U_{1,4}: 511.5 / U_{2,4}: 994.5 ; \mathrm{p}<0.05\right)$. In the low-density 3 for the density of Mother-calf pairs increases during the whole period $\left(U_{1,2}\right.$ : $\left.119 / U_{1,3}: 109 / U_{1,4}: 116 ; \mathrm{p}<0.05\right)$. The Other groups show an increase in density in the second period and a sharp decrease later on $\left(U_{1,2}: 56 / U_{1,3}: 82 / U_{1,4}: 71 / U_{2,4}: 308 ; \mathrm{p}<0.05\right)$.

Overall, when in a particular period in a high-density area the mean density for the period reaches around 3 whales per squared $\mathrm{km}^{2}$, the next period is characterized by a decrease of density in it. The process is also accompanied by an increase of density in the nearby low-density areas.

\section{Discussion}

This is the first study that proposes that a threshold in whale's density in breeding areas triggers a density-dependent response, it has been observed in other species of smaller size and in its majority of terrestrial environments (Matthysen 2005). This response includes the movement of Solitary Individuals and Breeding Groups (Other Groups) to adjacent areas when the average 
density in the area is close to 3 whales per $\mathrm{km}^{2}$. This must be taken with caution since it is an average from April to December for each period (Crespo et al. 2018). In any given season, as much as 15,87 whales per $\mathrm{km}^{2}$ can be found in the El Doradillo area for a few days (up to 15 days approximately) from the end of July until October. The inter-annual variation in the exact moment the maximum of whales is present in the area precludes us to use the census near the peak of the season because the surveys cannot always coincide with this peak in the number of whales. Hence, the density-dependent process proposed here cannot be observed using only the peak of the season but using the average of the density. Changes in the distribution of the Southern Right Whales in Peninsula Valdés were reported by Rowntree et al. (2001) during the late 80's. Rowntree et al. (2001) recorded a movement of whale breeding areas from the outer coast of Peninsula Valdés into the gulfs (Golfo Nuevo and Golfo San José), but no mechanism was proposed. The areas reported as new for the 1990s in Peninsula Valdés are the same as those observed in this work for the first period (Figure 2). Rowntree et al. (2001) considered several factors such as gull inflicted wounds or undetected changes in the environment and topography of the area as the possible causation of the observed shift in distribution. Our data lead us to propose that density changes (and probably related social causes) can be the main mechanism that promotes the search for new areas and the expansion of the occupied coast in Peninsula Valdés breeding ground. This mechanism might not have been the same mechanism that drove the changes observed during the late 1980's. Other social interactions not previously described in the area are being recorded. Mother-calf interactions and mating groups were almost exclusively the only social interaction recorded, but nowadays is possible to observe adult individuals without calves engaged in the same activities (e.g.: travelling together or socialize without forming a Breeding group) (Arias et al. 2017). Also, cooperative feeding was recorded recently (Argüelles 2017), and hence these new interactions never reported before may be shaping the social behaviour of whales in the area. These social aspects of the whales may have not been previously reported due to the low number of individuals until recent years. Mother-calf pairs continue to select areas used in the late 1990s, the so-called high-density zones (Figure 4). The density in these areas increased, but differentially by type of groups: while Mother-calf increased their density, the Other groups continue to select this area until an average threshold of 3 whales per $\mathrm{km}^{2}$ is reached. In every considered period, this is mainly due to the increase in density of Mother-calf. The only fraction of the population that is still growing, since 
201 the other type of groups have not shown positive increasing rates in the last few years (Crespo et 202 al. 2018). During the first period, the average annual density reached near 3 whales per $\mathrm{km}^{2}$ in

203

204

205

206

207

208

209

210

211

212

213

214

215

216

217

218

219

220

221

222

223

224

225

226

227

228

229

230

231 the area Puerto Madryn- El Doradillo. In the following period a change in the density of whales occurred (Figure 4); not only was there an increase in the Mother-calf pairs density, but the Other groups are more prone to be found in peripheral areas of less density (eg. low-density 1), as shown in Figure 3. The same pattern can be found in Golfo San José high-density area during the second period. After the mean density approached to 3 whales per $\mathrm{km}^{2}$, the density of the Other groups increased in the low-density 3 (Figure 5).

In the fourth period, it is observed that the average annual density of whales in the Doradillo area is close to 3 whales per $\mathrm{km}^{2}$. If the same pattern is repeated in the next period, we could hypothesize that an expansion of part of the whales to areas with physical and biological conditions similar to those found in Peninsula Valdes will occur in the next few years, as well as a new increase in the low-density areas.

In a context of population growth, the expansion into new areas is been driven by Solitary Individuals and Breeding groups (Arias et al. 2018). The optimum areas are first occupied by the Mother-calf pairs, as the density of this type group increases, the rest of the groups are displaced to suboptimal zones, as observed in the San Matias Gulf where the first groups in the area were the Solitary Individuals and Breeding groups (Svendsen 2013).

This kind of mechanism was recorded in other mammals. When the red deer (Cervus elaphus) population of the island of Rum doubled its size, females presented on average a greater spatial distance among them (Albon et al. 1992). In the case of roe deer (Cupreolus capreolus) their increase in density caused a change in the habitat use of young males and later of adult males. While females continue to use the habitat used by the population in the past (ie; optimal habitat), younger males tended to move to other areas (Vincent et al. 1995). Our results indicate that the recolonization process started at least in the mid-2000s when whales changed both the way they use the habitat related to the type of groups and the areas where they could be found. The expansion of these groups to other areas was observed in the province of Rio Negro with the presence of whales in the area near the San Antonio Bay. In this area, more than $80 \%$ of whales are Solitary Individuals and Breeding Groups (Arias et al. 2017; Crespo et al. 2018). These movements of Solitary Individuals and Breeding Groups move to new sites, outside the established breeding area has also been recorded in other southern right whale stocks from South 
232 Africa, New Zealand and southern Brazil, but no mechanism was ever proposed (Barendse \&

Best 2014; Carroll et al. 2014; Danilewicz et al. 2016).

234 Conclusion

235 The growth and expansion of the southern right whale population in Peninsula Valdés are proposed to being modelled by density-dependent determinants. One proposed mechanism is related to social mediated factors. It is important continuing to monitor the rate of increase in the core areas as well as the densities in these areas. The rate of increase of the population is now the combination of the increase recorded in Peninsula Valdés and the growth experienced while probably recolonizing ancient habitat (Arias et al. 2018; Crespo et al. 2018). Also, it is important to evaluate the habitat suitability of different areas, and to test if the mean density of around 3 individuals per $\mathrm{km} 2$ is an actual threshold that is also found outside Peninsula Valdés; and if so, which are the social causes that trigger this density-dependent response.

\section{Acknowledgements}

This paper is dedicated to our colleague Susana N. Pedraza, she was the most influential quantitative researcher at the Marine Mammal Laboratory. We thank S. Dans, G. Svendsen, M Degrati, F. Grandi, G. Garaffo, B. Berón Vera, L. Hardtke, F. García, A. Carribero, C. Giesse, D. Valés, R. Loizaga, J. Klaich, S. Leonardi, N. Martínez, V. Milano, M. Arias and C. Durante helped as observers or recorders in the flights. We thank several pilots throughout the period but mainly to Peter Dominguez.

\section{References}

Albon S, Staines H, Guinness F, and Clutton-Brock T. 1992. Density-dependent changes in the spacing behaviour of female kin in red deer. Journal of Animal Ecology:131-137.

Argüelles MB. 2017. Efectos de la navegación comercial y turística sobre la distribución, abundancia y comportamiento de las ballenas francas (Eubalaena australis) en el Golfo Nuevo, Chubut Doctorado en biologia. Universidad Nacional del Comahue.

Arias M, Coscarella MA, Romero MA, Svendsen GM, Reinaldo MO, Curcio NS, Crespo EA, and González RA. 2018. Impact of whale-watching on Southern Right Whale (Eubalaena australis) in Patagonia: Assessing the effects from its beginnings in the context of population growth. Tourism Management Perspectives 27:19.

Arias M, Coscarella MA, Svendsen GM, Romero MA, Curcio N, Sueyro N, Crespo EA, and González R. 2017. Changes in the distribution and abundance of Southern Right Whale Eubalaena australis in San Matías Gulf (Patagonia, Argentina). SC/67a/IWC Southern Right Whale Assessment Workshop.

Bannister J. 2001. Status of southern right whales (Eubalaena australis) off Australia. Journal of Cetacean Research and Management 2:103-110. 
Barendse J, and Best PB. 2014. Shore-based observations of seasonality, movements, and group behavior of southern right whales in a nonnursery area on the South African west coast. Marine Mammal Science 30:1358-1382.

Best PB, Brandão A, and Butterworth DS. 2001. Demographic parameters of southern right whales off South Africa. $J$ Cetacean Res Manage 2.

Carroll EL, Rayment WJ, Alexander AM, Baker CS, Patenaude NJ, Steel D, Constantine R, Cole R, Boren L, and Childerhouse S. 2014. Reestablishment of former wintering grounds by New Zealand southern right whales. Marine Mammal Science 30:206-220.

Cooke J. 2012. Southwest Atlantic right whales: updated population assessment from photo-id collected at Península Valdés, Argentina. IWC/64/Rep 1 Annex IWC Scientific Committee.

Cooke J, Rowntree V, and Payne R. 2001. Estimates of demographic parameters for southern right whales (Eubalaena australis) observed off Península Valdés, Argentina. J Cetacean Res Manage:125-132.

Cooke J, Rowntree V, and Sironi M. 2015. Southwest Atlantic right whales: interim updated population assessment from photo-id collected at Península Valdéz, Argentina. SC/66/IWC Southern Right Whale Assessment Workshop 23:9 pp.

Crespo EA, Pedraza SN, Dans SL, Svendsen GM, Degrati M, and Coscarella MA. 2018. The Southwestern Atlantic Southern Right Whale, Eubalaena australis, population is growing but at a decelerated rate. Marine Mammal Science:IN PRESS.

Danilewicz D, Moreno IB, Tavares M, and Sucunza F. 2016. Southern right whales (Eubalaena australis) off Torres, Brazil: group characteristics, movements, and insights into the role of the Brazilian-Uruguayan wintering ground. Mammalia.

Galletti Vernazzani B, Cabrera E, and Brownell RL. 2014. Eastern South Pacific southern right whale photo-identification catalog reveals behavior and habitat use patterns. Marine Mammal Science 30:389398.

Groch K, Palazzo Jr J, Flores P, Adler F, and Fabian M. 2005. Recent rapid increases in the right whale (Eubalaena australis) population off southern Brazil. Latin American Journal of Aquatic Mammals 4:41-47.

Hobbs NT, and Hanley TA. 1990. Habitat evaluation: do use/availability data reflect carrying capacity? The Journal of Wildlife Management:515-522.

IWC. 2001. Report of the workshop on the comprehensive assessment of right whales: a worldwide comparison. Journal of Cetacean Research and Management 2:1-60.

IWC. 2011. Report of the Workshop on the Southern Right Whale Assessment at Buenos Aires, Argentina.

IWC. 2012. Report of the IWC Workshop on the Assessment of Southern Right Whales. Document SC/64/Rep5 International Whaling Commission. Buenos Aires. p 1-39.

Matthysen E. 2005. Density-dependent dispersal in birds and mammals. Ecography 28:403-416.

Payne R. 1986. Long term behavioral studies of the southern right whale (Eubalaena australis). Report of the International Whaling Commission 10:161-167.

Payne R, Brazier O, Dorsey EM, Perkins JS, Rowntree V, and Titus A. 1981. External features in southern right whales (Eubalaena australis) and their use in identifying individuals: Report of the International Whaling Commission.

Payne R, Rowntree V, Perkins JS, Cooke JG, and Lankester K. 1990. Population size, trends and reproductive parameters of right whales (Eubalaena australis) off Peninsula Valdes, Argentina. Report of the International Whaling Commission:271-278.

Richards R. 2009. Past and present distributions of southern right whales (Eubalaena australis). New Zealand Journal of Zoology 36:447-459.

Rowntree V, Payne R, and Schell DM. 2001. Changing patterns of habitat use by southern right whales (Eubalaena australis) on their nursery ground at Península Valdés, Argentina, and in their long-range movements. Journal of Cetacean Research and Management 2:133-143.

Svendsen GM. 2013. Distribución y uso de hábitat de mamíferos marinos en el golfo San Matías. Universidad Nacional del Comahue. URL: http://rdi.uncoma.edu.ar/handle/123456789/175

Verner J, Morrison ML, and Ralph CJ. 1986. Wildlife 2000. Modeling habitat relationships of terrestrial vertebrates: University of Wisconsin Press. 
317 Vincent J, Bideau E, Hewison A, and Angibault J. 1995. The influence of increasing density on body weight, kid production, home range and winter grouping in roe deer (Capreolus capreolus). Journal of Zoology 236:371-382.

Whitehead H, Payne R, and Payne M. 1986. Population estimate for the right whales off Peninsula Valdes, Argentina, 1971-1976. Report of the International Whaling Commission:71-169.

Zar JH. 2010. Biostatistical analysis: Pearson Hall. 
Figure 1

Sampling area

The thick black line along the coast represent the surveyed area

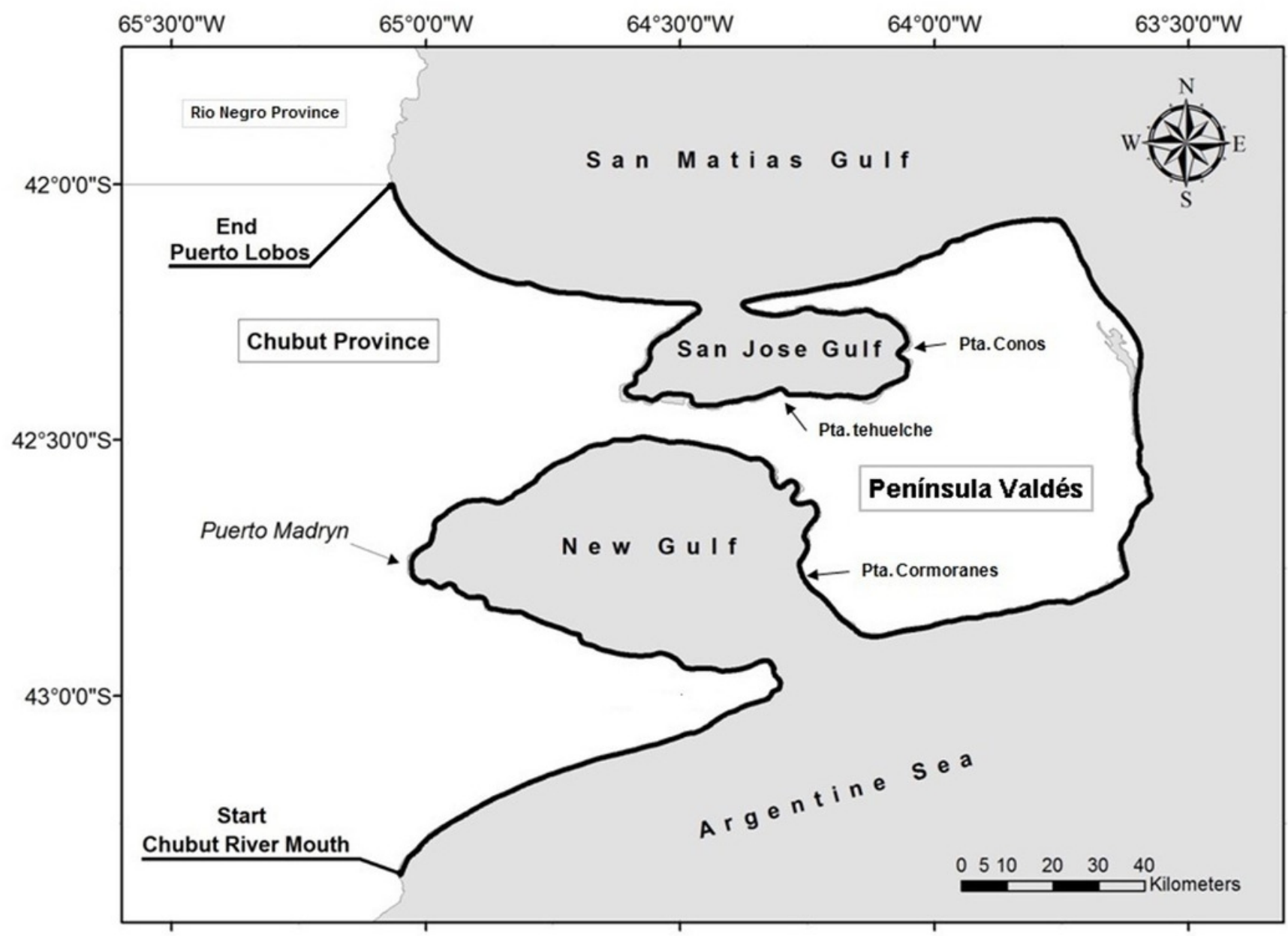


Figure 2

Variation of the average density of the sampling area for each established period.

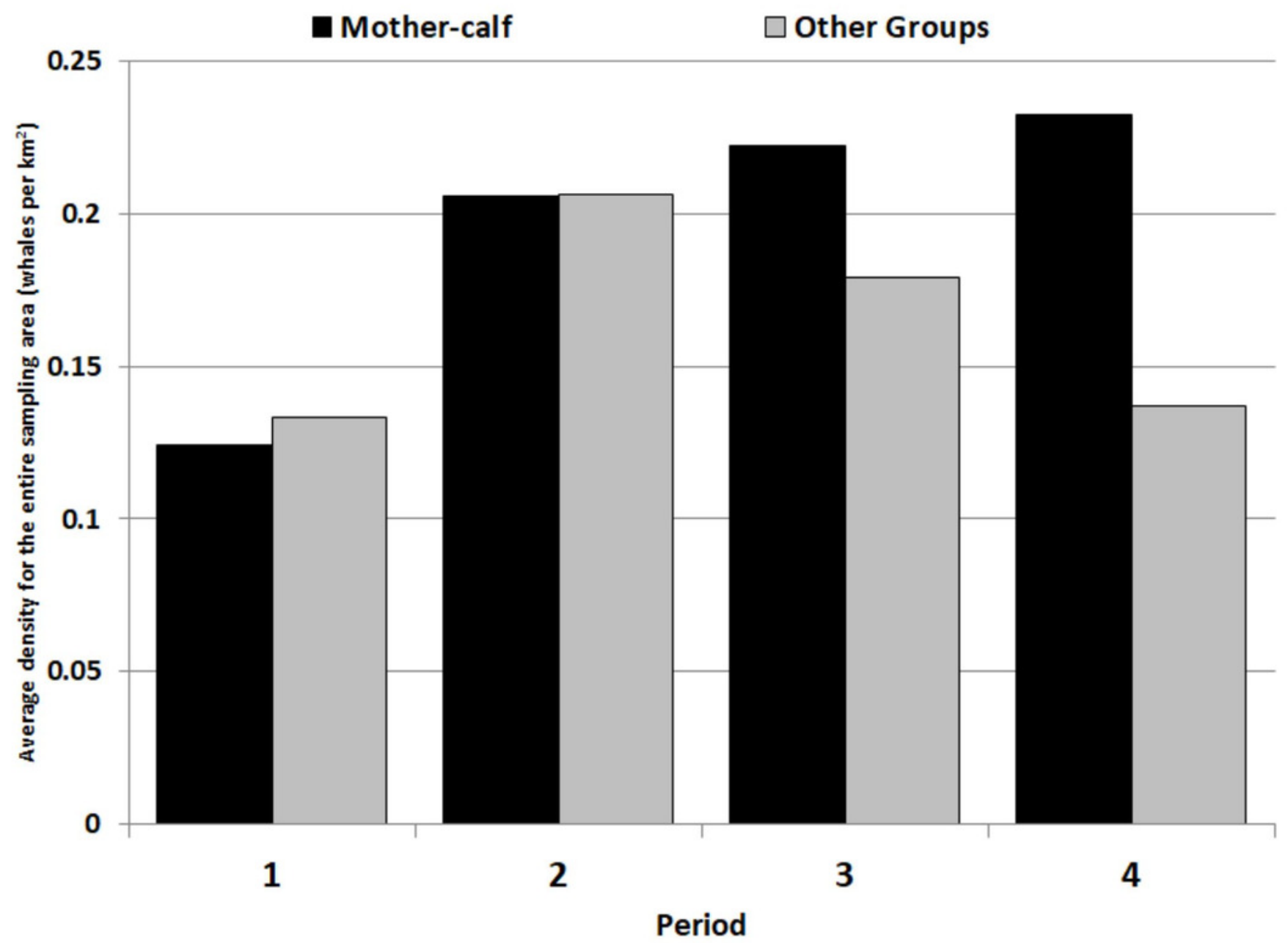


Figure 3

Density of the number of whales per $\mathrm{km}^{2}$ in each segment of $5 \mathrm{~km}$ performed in the 4 established periods for all the counted whales in the surveyed area.

Mother-calf pairs: white bars, Other groups: Black bar, All groups: gray continuous line.

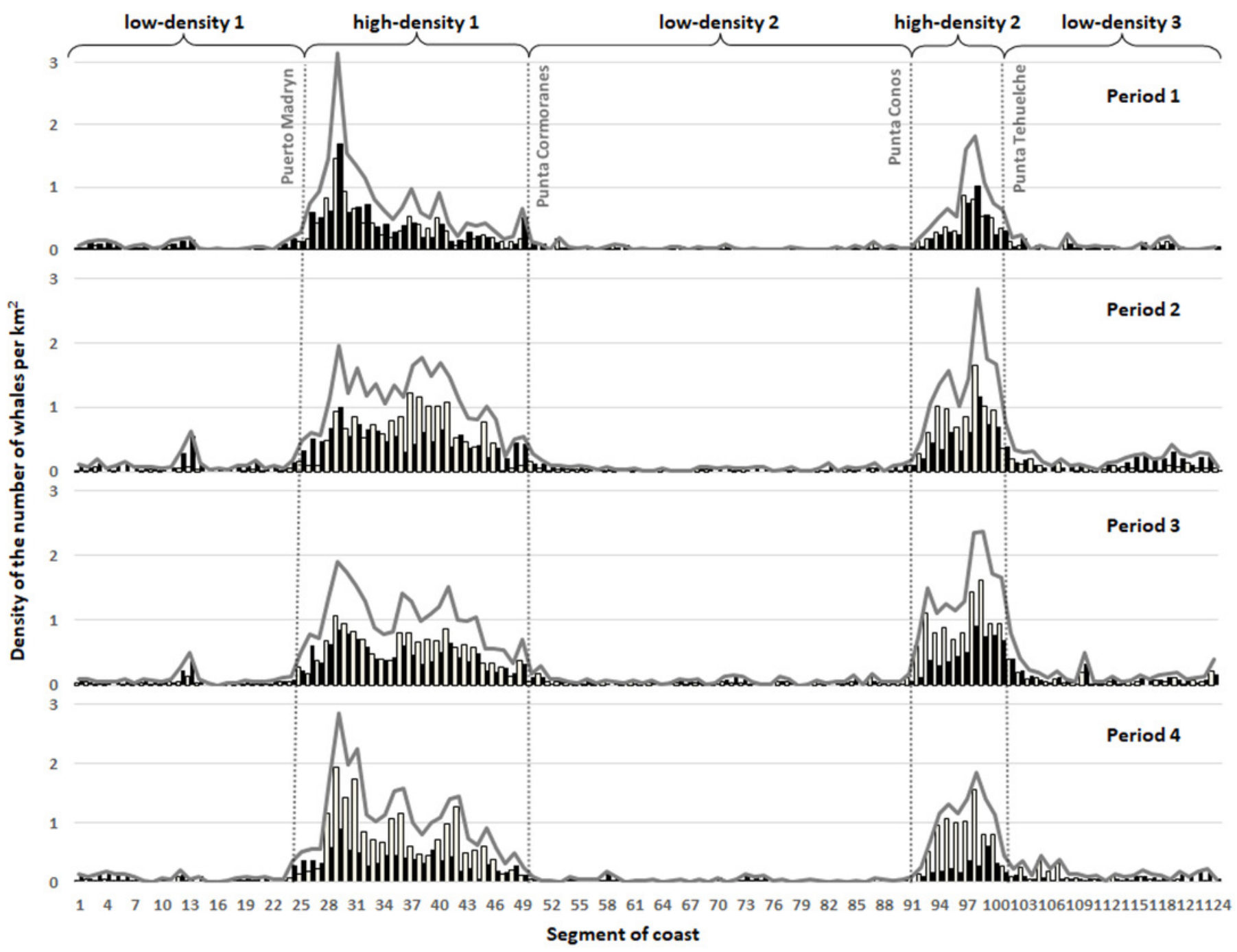


Figure 4

Variation of whale densities in the 4 periods for the three groups classified in the two high-density zones.

The brackets with the asterisk show the periods where there is a significant difference

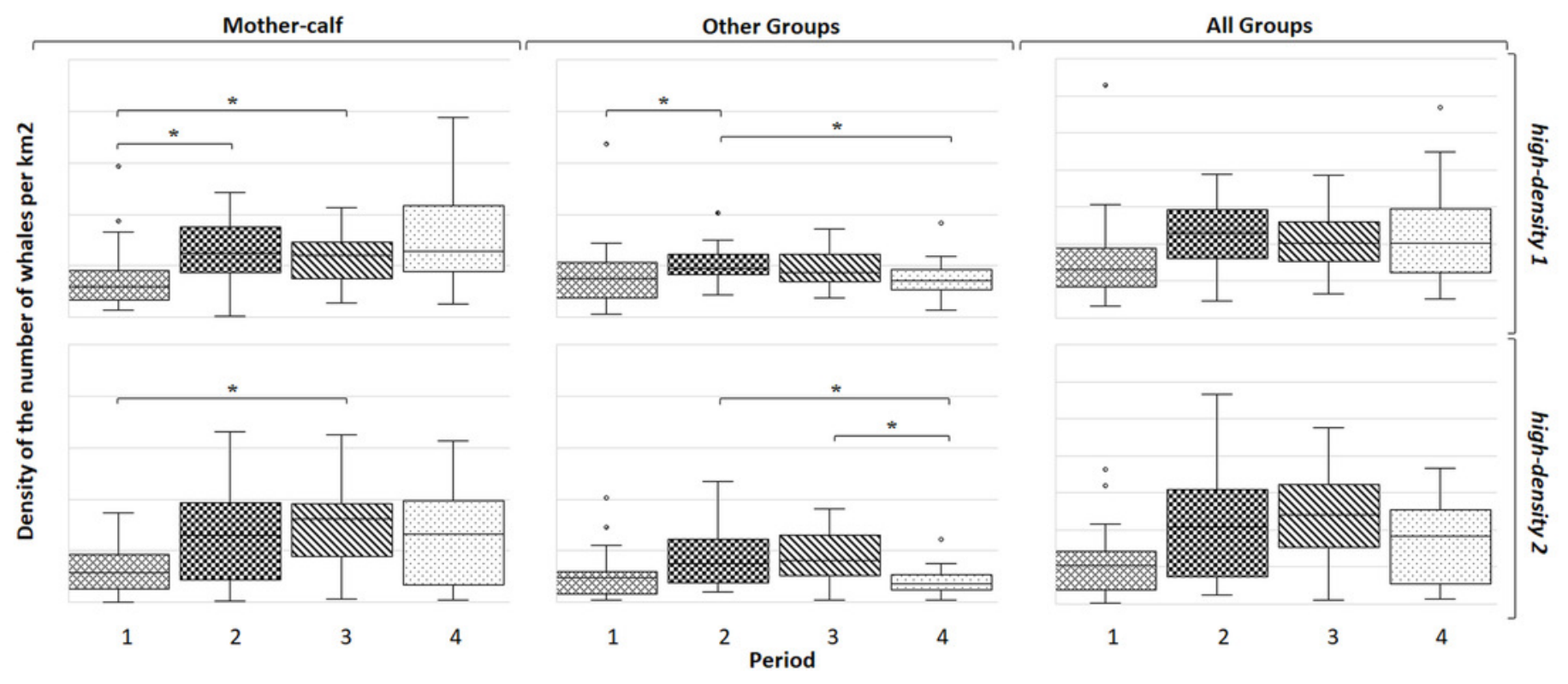


Figure 5

Mean densities of whales in the 4 periods for the three groups classified in the three low-density zones.

The brackets with the asterisk show the periods where there is a significant difference.

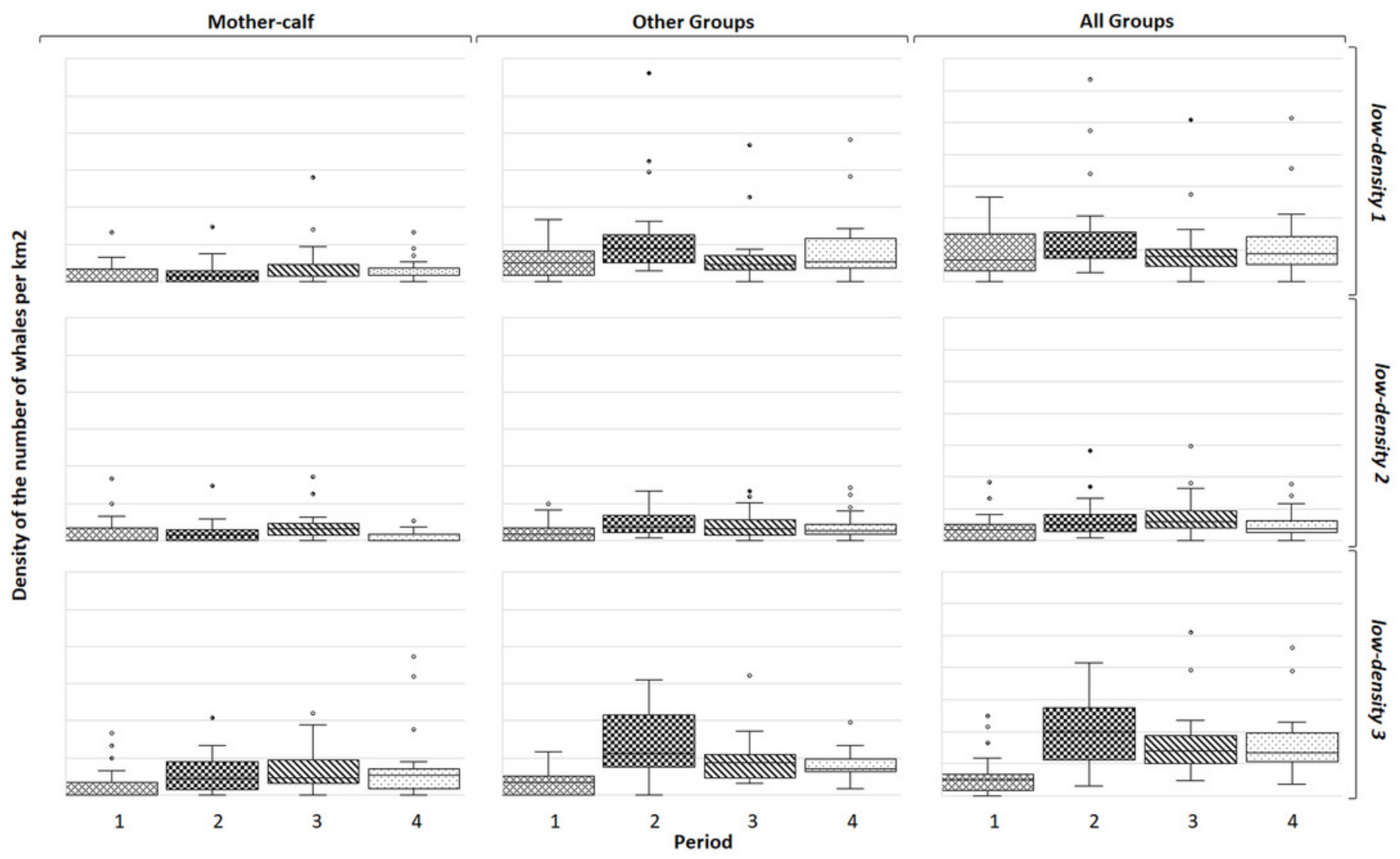

